\title{
Perception of body image by patients undergoing bariatric surgery
}

\section{Percepção da imagem corporal em pacientes submetidos à cirurgia bariátrica}

\author{
Rosana Maria Resende lacerda"; Christiane Ramos Castanha ${ }^{2}$; Alessandra Ramos Castanha ${ }^{2}$; Josemberg Marins Campos,
} TCBC-PE'; Álvaro Antônio Bandeira Ferraz, TCBC-PE ${ }^{1}$; LuCIO VILAR ${ }^{1}$

A B S T R A C T

\begin{abstract}
Objective: to investigate changes in body image perception in patients undergoing bariatric surgery, evaluating the accuracy/inaccuracy in body size estimation and satisfaction/dissatisfaction with own body after surgery. Methods: we performed a survey at the General Surgery outpatient clinic of the Clinics Hospital of the Federal University of Pernambuco. Thirty-six patients aged 18 years and older undergoing bariatric surgery participated. We carried out cross-sectional and quantitative studies using the Silhouetted Figures Scale. Results: in the descriptive analysis of the distortion and dissatisfaction score of the patients with the body image, the mean distortion was positive $\left(6.43 \mathrm{~kg} / \mathrm{m}^{2}\right)$, indicating that most people see themselves greater than they really are. On the other hand, in the dissatisfaction, we found a negative mean $\left(-6.91 \mathrm{~kg} / \mathrm{m}^{2}\right)$, indicating that the majority of the patients evaluated had a "BMI" lower than the current one (that is, a smaller silhouette). Regarding satisfaction with silhouette size, only $11.8 \%$ of women liked the post-surgical result, while among men there was 50\% satisfaction. Conclusion: Although bariatric surgery significantly reduced BMI, the patients presented, for the most part, dissatisfaction with body weight, perceiving it greater than it actually was, thus characterizing a perceptual inaccuracy.
\end{abstract}

Keywords: Perception. Body image. Patient Satisfaction. Body Mass Index. Bariatric Surgery.

\section{INTRODUCTION}

In addition to physical burdens, obesity has a psychological impact that can reflect on body image disorders, low self-esteem, anxiety, depression, and a social impact that negatively reflects on professional life and interpersonal relationships ${ }^{1}$. In this context, undergoing weight loss treatments may not only be related to the need or desire for physical health, but also psychological and social one ${ }^{2}$, since massive weight loss has effects, for example, on the alteration of body image perception and self-esteem ${ }^{3}$.

Body image is a multidimensional construct that involves cognitive, cultural, and physiological aspects. It concerns the perception and feeling one has in relation to one's own body. Distortions in body image generally promote a feeling of rejection or dissatisfaction ${ }^{4-6}$. The study of body image is extremely relevant in cases of eating disorders, since in abnormal eating behavior the perception of body weight may be a more determining factor than the objective reality of its appearance ${ }^{7}$.

Bariatric surgery (BS) leads to several changes in weight and body contours. However, the body image will not always immediately follow these adjustments. Psychological alterations may require a longer time of symbolic elaboration, a perception of obese body image persisting even with significant and expected weight loss. Perceptual restructuring tends to be slower than rapid and massive weight loss ${ }^{4,8}$. This rapid and massive weight loss after BS can concomitantly lead to the recovery of self-esteem and cause dissatisfaction of the body image, due to either inadequate perceptual restructuring or to direct consequences of surgery itself, such as sagging skin in the breasts and in the abdomen, in addition to extensive scars ${ }^{3}$.

1 - Federal University of Pernambuco, Department of Surgery and Clinical Medicine, Recife, PE, Brazil. 2 - Federal University of Pernambuco, Department of Psychology, Recife, PE, Brazil. 
Some authors state that dissatisfaction with body image can lead to behaviors harmful to health, such as adherence to inappropriate diets, as well as the emergence of psychopathologies such as anorexia, bulimia and body dysmorphia. These are aggravated in patients submitted to BS, since it can hinder adherence to the new habits required, resulting in negative consequences, such as weight regain, nutritional deficiencies and even the risk of death ${ }^{9,10}$. In this sense, self-perception and satisfaction with body image are fundamental for self-acceptance, and justifies the importance of the study of body image perception after bariatric surgery ${ }^{11}$.

This research sought to investigate changes in body image perception in patients submitted to BS, evaluating the accuracy/inaccuracy in body size estimation and body satisfaction/dissatisfaction after surgery.

\section{METHODS}

We performed the research at the Outpatient Clinic of General Surgery of the Clinics Hospital of UFPE (HC-UFPE). We carried out cross-sectional and quantitative studies. Participants were 36 patients of both genders, aged between 22 and 63 years, who underwent surgery for a maximum of seven years. The Silhouetted Figures Scale (SFS) was composed of silhouettes of both sexes and Body Mass Index (BMI) averages varying from 12.5 to $47.5 \mathrm{~kg} /$ $\mathrm{m}^{2}$. We presented the patients the SFS cards in ascending order (from thinnest figure to largest) and asked them to choose: a) the card that represented the silhouette of their current body; b) the card that represented the silhouette of a body that they would like to have.
To analyze the data, we built a dataset in a Microsoft Excel spreadsheet, which was exported to the Statistical Package for the Social Sciences (SPSS), version 18, where we performed the analysis. We described the anthropometric data with mean, standard deviation, median, minimum and maximum. We also constructed the degree of distortion through the difference of the BMI chosen by the patients and the actual BMI. For the construction of the degree of dissatisfaction, we calculated the difference between the desired BMI and the current BMI. We used the Kolmogorov-Smirnov test to assess the normality of the distortion and dissatisfaction scores. In cases showing normality of the score, we used the Student's t-test for independent samples and the ANOVA test to compare two or three and more groups, respectively. To compare the dissatisfaction score with the distortion score, we used the Student's t-test for paired samples. We drew all conclusions considering the level of significance of $5 \%$. We used a $95 \%$ truth force $(p=0.05)$.

The study was approved by the Ethics in Research Committee of the Health Sciences Center (CCS) of the Federal University of Pernambuco (CAAE: 26602314.7.0000.5208).

\section{RESULTS}

Table 1 shows the descriptive analysis of the patient's anthropometric data. The average weight before surgery was $115.94 \mathrm{~kg}$, with a standard deviation (SD) of $19.56 \mathrm{~kg}$. The mean weight after surgery was $79.53 \mathrm{~kg}$, with SD $21 \mathrm{~kg}$. Mean height was $159 \mathrm{~cm}$.

Table 1. Distribution of anthropometric data.

\begin{tabular}{lccccc}
\hline \multicolumn{1}{c}{ Variable } & Mean & SD & Minimum & Median & Maximum \\
\hline Weight $(\mathrm{KG})$ & & & & & \\
Before & 115.94 & 19.56 & 82.00 & 110.00 & 166.00 \\
After & 79.53 & 16.78 & 51.90 & 76.00 & 119.00 \\
Height $(\mathrm{cm})$ & 159 & 0.07 & 149 & 158 & 181 \\
\hline
\end{tabular}

Before BS, we divided patients into two categories, obesity grades II and III, with the predominance of the latter, which affected $82.4 \%$ of the patients. After the surgical procedure, the majority of patients presented grade I obesity (35.3\%), followed by overweight (29.4\%), normal weight (14.7\%), grade II obesity $(11.8 \%)$, and 
grade III obesity (8.8\%).

Table 2 shows the descriptive analysis of patients' distortion score and dissatisfaction of with body image. The mean distortion was positive $(6.43 \mathrm{~kg} /$ $\left.\mathrm{m}^{2}\right)$, indicating that most people see themselves bigger than they really are. On the other hand, in the dissatisfaction, we found a negative mean $\left(-6.91 \mathrm{~kg} / \mathrm{m}^{2}\right)$, indicating that the majority of the patients evaluated had a "BMI goal" lower than the current one (that is, a smaller silhouette).

Table 2. Characterization of distortion and dissatisfaction.

\begin{tabular}{lcccccc}
\hline \multicolumn{1}{c}{ Variable } & Mean & SD & Minimum & Median & Maximum & $p_{\text {-value }}$ \\
\hline Distortion & 6.43 & 5.14 & -4.57 & 6.61 & 17.63 & $<0.001$ \\
Dissatisfaction & -6.91 & 6.40 & -30.00 & -5.00 & 5.00 & \\
\hline
\end{tabular}

1 Student's t-test for paired samples (If $p$-value $<0.05$, Distortion differs from the Dissatisfaction).

In the female group, the mean value of the current BMI was $37.86 \mathrm{~kg} / \mathrm{m}^{2}( \pm 6.22)$, while the mean desired BMI was $30.88 \mathrm{~kg} / \mathrm{m}^{2}( \pm 4.64)$. In men, the current BMI mean was $35.0 \mathrm{~kg} / \mathrm{m}^{2}( \pm 0)$ and the desired BMI was $30 \mathrm{~kg} / \mathrm{m}^{2}( \pm 7.07)$.

As for image distortion according to gender, $87.5 \%$ of women presented overestimation (that is, they saw themselves bigger than they really were), while the male group showed $100 \%$ overestimation. Therefore, we found no significant relationship between gender and image overestimation.

Regarding dissatisfaction with body image according to gender, we found that $85.3 \%$ of the women wished to decrease the size of the silhouette, while in the male group this percentage was $50 \%$. As for satisfaction with silhouette size, only $11.8 \%$ of women liked the post-surgical result, while among men there was $50 \%$ satisfaction.

Table 3 shows the descriptive analysis of the dissatisfaction score and body image distortion according to gender. We observed that both in the female and in the male groups the mean dissatisfaction was negative $\left(-7.03 \mathrm{~kg} / \mathrm{m}^{2}\right.$ and $-5.0 \mathrm{~kg} / \mathrm{m}^{2}$, respectively), indicating that they wanted to have a smaller silhouette. For the distortion, we found positive mean score values $(6.60 \mathrm{~kg} /$ $\mathrm{m}^{2}$ for females and $3.72 \mathrm{~kg} / \mathrm{m}^{2}$ for males), indicating that patients of both genders overestimated their body image.

Table 3. Descriptive analysis of the dissatisfaction score and distortion of body image according to gender.

\begin{tabular}{llcccccc}
\hline \multicolumn{1}{c}{ Gender } & \multicolumn{1}{c}{ Variable } & $\mathrm{n}$ & Mean & SD & Minimum & Median & Maximum \\
\hline \multirow{2}{*}{ Female } & Dissatisfaction & 32 & -7.03 & 6.46 & -30.00 & -5.00 & 5.00 \\
& Distortion & 32 & 6.60 & 5.20 & -4.57 & 6.80 & 17.63 \\
\multirow{2}{*}{ Male } & Dissatisfaction & 2 & -5.00 & 7.07 & -10.00 & -5.00 & 0.00 \\
& Distortion & 2 & 3.72 & 4.11 & 0.81 & 3.72 & 6.63 \\
\hline
\end{tabular}

Table 4 presents the descriptive analysis of the body image dissatisfaction and distortion score according to postoperative time. There was a higher mean level of dissatisfaction with body image in the group of patients submitted to surgery up to six months $\left(-9.50 \mathrm{~kg} / \mathrm{m}^{2} \pm 3.26\right)$, followed by the group within 12 and 24 months $(-7.71 \mathrm{~kg} /$ $\left.\mathrm{m}^{2} \pm 5.59\right)$ and the one over 24 months $\left(-6.67 \mathrm{~kg} / \mathrm{m}^{2}\right.$ $\pm 9.10)$. For the body image distortion, we found a higher mean score in the group of patients with 12 to 24 months postoperative $\left(7.42 \mathrm{~kg} / \mathrm{m}^{2} \pm 5.10\right)$, followed by the group with six to 12 months $\left(7.06 \mathrm{~kg} / \mathrm{m}^{2} \pm 4.72\right)$ and more than 24 months postoperatively $\left(5.94 \mathrm{~kg} / \mathrm{m}^{2} \pm 6.56\right)$. 
Table 4. Descriptive analysis of the dissatisfaction score and distortion of body image the according to the patient's postoperative period.

\begin{tabular}{lllllllc}
\hline \multicolumn{1}{c}{ Postoperative Period } & \multicolumn{1}{c}{ Variable } & $\mathrm{n}$ & Mean & $\mathrm{SD}$ & Minimum & Median & Maximum \\
\hline \multirow{2}{*}{ Up to 6 months } & Dissatisfaction & 5 & -9.50 & 3.26 & -12.50 & -10.00 & -5.00 \\
& Distortion & 5 & 3.94 & 3.03 & -0.58 & 5.06 & 6.59 \\
\multirow{3}{*}{6 to 12 months } & Dissatisfaction & 8 & -4.38 & 5.47 & -10.00 & -6.25 & 5.00 \\
& Distortion & 8 & 7.06 & 4.72 & -0.14 & 7.38 & 12.54 \\
12 to 24 months & Dissatisfaction & 12 & -7.71 & 5.59 & -17.50 & -5.00 & 0.00 \\
& Distortion & 12 & 7.42 & 5.10 & -3.81 & 7.22 & 14.86 \\
Over 24 months & Dissatisfaction & 9 & -6.67 & 9.10 & -30.00 & -5.00 & 0.00 \\
& Distortion & 9 & 5.94 & 6.56 & -4.57 & 5.69 & 17.63 \\
\hline
\end{tabular}

\section{DISCUSSION}

Data showed that, regardless of gender, there was a distortion of body image $\left(6.43 \mathrm{~kg} / \mathrm{m}^{2} \pm 5.14\right)$. As the value of the distortion was positive, this indicates a tendency to overestimate the body image, that is, the majority of the participants of the research saw themselves bigger than they really are. These data corroborate, in part, the existing literature, since studies point to divergent conclusions regarding the distortion of body image in obese individuals, who can either underestimate or overestimate body size.

In a study with 100 patients of both genders submitted to BS, Rezende ${ }^{10}$ observed a tendency to underestimation of body image, with negative distortion values both in men and in women $\left(-0.94 \mathrm{~kg} / \mathrm{m}^{2} \pm 6.88\right.$ and $-0.77 \mathrm{~kg} / \mathrm{m}^{2} \pm 6.45$, respectively), thus showing that the majority of the participants perceived themselves thinner than they really were. Underestimation can occur because of the difficulty in estimating body size after rapid weight loss. Another factor that can lead to inaccuracy of body weight reckoning is the desire to move away from stereotypes that usually accompany obese life, such as laziness, lack of self-control and will power. These stereotypes generate psychic suffering, whether conscious or unconscious, and can lead individuals to underestimate their body sizes, functioning as a defense mechanism, through denial of a body that does not fit into the current patterns ${ }^{12}$.

Among the studies that corroborate the results of the present one, that is, those in which the majority of the participants tended to overestimate body size, we can cite the research with 50 women who had undergone BS, which demonstrated that patients had expected weight loss and improved obesity-associated comorbidities, as well as improved symptoms of anxiety and depression ${ }^{12}$. However, they still had body image disturbances and $62 \%$ of them overestimated their actual body size on an average of $3.9 \mathrm{~kg} / \mathrm{m}^{2}$ and were dissatisfied with their own image, wishing to weigh less. Some authors affirm that the patients have the belief that BS will be the solution of their problems. When they perceive that this is not the case, "a search for a dreamed and idealized body begins, which most of the times does not materialize. In that moment, deviation of self-image, frustration and depression arise" 13 . A factor that can lead to overestimation is the incidence of obesity during childhood. The earlier obesity ensues, the greater the incidence of preoccupation with body image and a threefold higher chance of overestimating body size when compared with normal adults ${ }^{14}$.

We found a negative dissatisfaction mean $\left(-6.91 \mathrm{~kg} / \mathrm{m}^{2} \pm 6.40\right)$, indicating that most patients have a "goal" of having a lower BMl than the current one, that is, they want to have a smaller silhouette. A study of 50 women in BS pre- and postoperative (four months) periods, using three instruments, among them the 
Silhouettes Figure Scale, demonstrated that all patients were dissatisfied with body image, on average, a BMI of $10.3 \mathrm{~kg} / \mathrm{m}^{2}$ less than they thought they had ${ }^{12}$.

BS is effective in weight loss, which reduces depreciation of body image, brings more disposition to the working life and allows a better resourcefulness in the physical, social and sexual activities, thus increasing the self-esteem as a whole, causing a positive impact in the patient's psychosocial behavior ${ }^{15,16}$. On the other hand, the negative evaluation of the body image itself can worsen the prognosis, compromising treatment success, understanding that it does not end with $\mathrm{BS}^{12}$.

A study conducted by Segura et al. ${ }^{17}$ with 50 individuals (36 women and 14 men) with a mean age of $43.82( \pm 12.2)$ years and a mean postoperative time of 34.8 months $( \pm 22.0)$ indicated that BMl showed a direct relationship between body image and level of satisfaction with weight. These data are in line with those found in the present study, as well as in others performed by several authors, which observed that it is not BMI that will necessarily establish the relationship between body image and satisfaction level, but with the self-image of perceived obesity, that is, through a subjective evaluation, not related to the actual weight of the individual ${ }^{18-20}$. Still in this sense, Palmeira et al..$^{20}$ state that BS patients who can improve in psychological aspects such as changes in self-esteem, body image, depression and mood, tend to have an adaptation to this new body in a more positive way, as well as being able to maintain weight reduction in the long run because they feel more motivated.

In view of the above, it is important to work with patients who remain dissatisfied with their body image after BS, in an attempt to understand the intrinsic and extrinsic factors that are negatively influencing it, so that they can re-evaluate this new body positively. When analyzing the mean of the actual $\mathrm{BMI}$ (collected in the chart), the perceived (indicated on the silhouette scale) and the desired one (also indicated in the silhouette scale), we observed that despite the actual BMI $\left(31.21 \mathrm{~kg} / \mathrm{m}^{2}\right)$ was quite close to the desired one $\left(30.83 \mathrm{~kg} / \mathrm{m}^{2}\right)$, the participants had a perceptual inaccuracy, since they perceived a mean BMl of $37.71 \mathrm{~kg} / \mathrm{m}^{2}$, that is, a larger silhouette than they actually possessed, leading to a greater degree of dissatisfaction, suffering, and anguish.

Sarwer et al. ${ }^{21}$ affirm that the subjective perception about self-image may even be more important than the objective reality itself of its appearance. In this context, the analysis of the data of the present research is that, regardless of the actual BMl being close to the desired BMI, what really matters is how the patients perceive their bodies and, in this case, the perception is distorted, increased. Cordás et al. ${ }^{18}$ state that this distortion may be influenced by some factors, and that one of them is the age at which the obesity picture began. The authors argue that the earlier it is, the more difficult it will be to adapt to this new body, over which often individuals continue to project an image of a fat body with which they have always identified, even having lost weight.

We observed that, as effective as BS might have been, as evidenced by the BMI and weight loss indexes, as well as by the proximity of the mean values of the actual and desired BMI, it is evident the difficulty of the investigated patients in perceiving not only the improvement in body contour, but how much this improvement was so close to what they would wish to possess. This difficulty occurs due to perceptual inaccuracy, through the distortion of the subjective body perception.

After BS, there are weight loss and changes in body contours that happen rapidly. Often the individual cannot psychologically assimilate this new body image, and a perception of an obese body can remain, until the perceptive, cognitive restructuring can occur in an effective way, bringing the actual weight closer to what the individual perceives to have at that moment ${ }^{4,8}$. Still in this sense, Branco et al. ${ }^{11}$ affirm that self-acceptance is directly related to the way in which one perceives oneself and how satisfied one is with one's own body image. The dissatisfaction with body image in patients submitted to BS can negatively affect self-esteem, interpersonal relationships, cause anxiety and depression, may also hamper the necessary adaptation related to adherence 
to medical and nutritional recommendations, and lead to weight regain, nutritional deficiencies and, in more serious cases, the risk of death ${ }^{\text {. }}$.

When analyzing the distribution of patients' dissatisfaction with body image according to gender, we noticed that women have a higher dissatisfaction index. Regarding the size of the silhouette, $85.3 \%$ of women wanted it smaller, while in the men's group this percentage was $50 \%$. Regarding satisfaction with silhouette size, only $11.8 \%$ of women liked the postoperative result, while men presented a $50 \%$ satisfaction index. The difference found between genders in regard to dissatisfaction may be based on gender issues, in which, culturally, there is the cult of thinness as an acceptable/desirable aesthetic pattern and this is a factor that affects women much more, because they suffer a much greater charge of society in relation to their body. In addition, men tend to seek the BS's appeal motivated much more by the limitations that obesity brings in daily activities than by aesthetic reasons per se. Rezende ${ }^{10}$ conducted a survey of 85 women and 15 men and found more homogeneous data when comparing these two groups. In both genders, $80 \%$ of the participants wished to decrease their silhouette and, in the comparison regarding silhouette satisfaction after BS, $15 \%$ of the women and $20 \%$ of the men were satisfied. Despite finding a smaller difference between the two groups, the author also found a slightly lower index of satisfaction with the postoperative result among women.
When analyzing the body image dissatisfaction and distortion score according to the postoperative period, there was a higher level of dissatisfaction in the group of patients submitted to BS up to six months $\left(-9.50 \mathrm{~kg} / \mathrm{m}^{2} \pm 3.26\right)$ followed by the group in the 12 to 24 months postoperative period $\left(-7.71 \mathrm{~kg} / \mathrm{m}^{2} \pm 5.59\right)$ and the one over 24 months $\left(-6.67 \mathrm{~kg} / \mathrm{m}^{2} \pm 9.10\right)$. As for distortion, we found the highest mean score in the group of patients within 12 to 24 postoperative months $\left(7.06 \mathrm{~kg} / \mathrm{m}^{2} \pm 4.72\right)$. The highest index of dissatisfaction in the group of up to six months can be explained by the fact that the postoperative time was not enough for the desired weight loss. Regarding groups of 12 to 24 months and over 24 months, it can be explained by the expected weight regain from the second year after surgery on ${ }^{22}$.

These negative feelings, which arise over time, are also accompanied by the increase in weight that comes with the years of surgery. In this way, there is need for a multidisciplinary follow-up after BS, with the participation of professionals from the medical, psychological, nutritional and physical educator areas, thus providing a better adaptation to a permanent habit change and maintenance of surgical results ${ }^{22}$.

We conclude that although BS had a significant decrease in BMI, the patients presented, for the most part, dissatisfaction with body weight, perceiving it greater than it actually was, thus characterizing a perceptual inaccuracy.

\section{R E S U M O}

\footnotetext{
Objetivo: investigar as mudanças sofridas na percepção da imagem corporal em pacientes submetidos à cirurgia bariátrica, avaliando a acurácia/inacurácia na estimativa do tamanho corporal e a satisfação/insatisfação com os corpos após a cirurgia. Métodos: pesquisa foi realizada no ambulatório de Cirurgia Geral do Hospital das Clínicas da Universidade Federal de Pernambuco. Participaram 36 pacientes com idade a partir de 18 anos submetidos à cirurgia bariátrica. Foram realizados estudos transversal e quantitativo com a utilização da Escala de Figuras de Silhuetas. Resultados: na análise descritiva do escore de distorção e insatisfação dos pacientes com a imagem corporal, percebeu-se que a média da distorção foi positiva (média $=6,43 \mathrm{~kg} / \mathrm{m}^{2}$ ), indicando que a maioria das pessoas se vê maior do que realmente é. Em contrapartida, na insatisfação foi encontrada uma média negativa (média= $-6,91 \mathrm{~kg} / \mathrm{m}^{2}$ ), indicando que a maioria dos pacientes avaliados tem como "meta" um IMC menor do que aquele apontado como atual (ou seja, gostaria de ter uma silhueta menor). Quanto à satisfação com o tamanho da silhueta, apenas $11,8 \%$ das mulheres gostaram do resultado pós-cirúrgico, enquanto que entre os homens houve $50 \%$ de satisfação. Conclusão: embora a cirurgia bariátrica tenha diminuído significativamente o IMC, os pacientes apresentaram, em sua maioria, insatisfação com o peso corporal, percebendo-o maior do que realmente era, caracterizandose, assim, uma inacurácia perceptiva.
}

Descritores: Percepção. Imagem Corporal. Satisfação do Paciente. Índice de Massa Corporal. Cirurgia Bariátrica. 


\section{REFERÊNCIAS}

1. de Zwaan $M$, Enderle J, Wagner S, Mühlhans B, Ditzen B, Gefeller O, et al. Anxiety and depression in bariatric surgery patients: a prospective, followup study using structured clinical interviews. J Affect Disord 2011;133(1-2):61-8.

2. Almeida GAN, Santos JE, Pasian SR, Loureiro SR. Percepção de tamanho e forma corporal de mulheres: estudo exploratório. Psicol Estud. 2005;10(1):27-35.

3. Castro MR. Imagem corporal de mulheres submetidas à cirurgia bariátrica [dissertação]. Juiz de Fora (MG): Universidade Federal de Juiz de Fora; 2009.

4. Tavares MCGF. Imagem corporal: conceito e desenvolvimento. São Paulo: Manole; 2003.

5. Adami F, Fernandes TC, Frainer DES, Oliveira FR. Aspectos da construção e desenvolvimento da imagem corporal e implicações na educação física. Rev Digit [Internet]. 2005 [citado 2017 Nov 13];83(10):[cerca de 1 p]. Disponível em: http://www. efdeportes.com/efd83/imagem.htm

6. Friedman MA, Brownell KD. Psychological correlates of obesity: moving to the next research generation. Psychol Bull. 1995;117(1):3-20.

7. Nunes MA, Olinto MTA, Barros FC, Camey S. Influência da percepção do peso e do índice de massa corporal nos comportamentos alimentares anormais. Rev Bras Psiquiatr. 2001;23(1):21-7.

8. Pruzinsky T, Edgerton M. Body-image change in cosmetic plastic surgery. In: Cash TF, Pruzinsky T, editors. Body images: development, deviance, and change. New York: Guilford Press; 1990. p. 190236.

9. McCabe MP, Ricciardelli LA. Body image dissatisfaction among males across the lifespan: a review of past literature. J Psychosom Res. 2004;56(6):675-85.

10. Rezende FF. Percepção da imagem corporal, resiliência e estratégias de coping em pacientes submetidos à cirurgia bariátrica [dissertação]. Ribeirão Preto (SP): Universidade de São Paulo; 2011.

11. Branco LM, Hilário MOE, Cintra IP. Percepção e satisfação corporal em adolescentes e a relação com seu estado nutricional. Rev Psiquiatr Clin.
2006;33(6):292-6.

12. Oliveira MP, Siqueira EJ, Alvarez GS, Laitano FF, Pires FKS, Martins PDE. Aspectos psicológicos do paciente pós-bariátrico. Arq Catarinen Med. 2012;41(Supl 1):173-5.

13. Fandiño JN, Apolinário JC. Avaliação psiquiátrica da cirurgia bariátrica. In: Nunes MA, Appolinário JC, Galvão AL, Coutinho W, editores. Transtornos alimentares e obesidade. Porto Alegre: Artmed; 2006. p. 365-54.

14. Ceneviva R, Silva GA, Viegas MM, Sankarankutty AK, Chueire FB. Cirurgia bariátrica e apneia do sono. Medicina (Ribeirão Preto). 2006;39(2):235-45.

15. Castanha CR. Avaliação da qualidade de vida, perda de peso e comorbidades de pacientes submetidos à cirurgia bariátrica [dissertação]. Recife (PE): Universidade Federal de Pernambuco; 2017.

16. Boscatto EC, Gomes MA, Duarte MFS. Comportamentos ativos e percepção da saúde em obesos submetidos à cirurgia bariátrica. Rev Bras Atividade Fís Saúde. 2012;16(1):43-7.

17. Segura DCA, Corral JP, Wozniak SD, Scaravonatto A, Vandresen EP. Análise da imagem corporal e satisfação com o peso em indivíduos submetidos à cirurgia bariátrica. Rev Pesqui Saúde. 2016;17(3):1704.

18. Cordás TA. Participação do psiquiatra e do psicólogo na fase perioperatória: a participação do psiquiatra. In: Garrido Jr AB, editor. Cirurgia da obesidade. São Paulo: Atheneu; 2002. p. 71-4.

19. Barros LM, Moreira RAN, Frota NM, Caetano JA. Mudanças na qualidade de vida após a cirurgia bariátrica. Rev Enferm UFPE online. 2013;7(5):136575.

20. Palmeira AL, Branco TL, Martins SC, Minderico CS, Silva MN, Vieira PN, et al. Change in body image and psychological well-being during behavioral obesity treatment: associations with weight loss and maintenance. Body Image. 2010;7(3):187-93.

21. Sarwer DB, Wadden TA, Foster GD. Assessment of body image dissatisfaction in obese women: specificity, severity, and clinical significance. J Consult Clin Psychol. 1998;66(4):651-4. 
22. Franques ARM, Arenales-Loli MS. Novos corpos, novas realidades: reflexões sobre o pós-operatório da cirurgia da obesidade. São Paulo: Vetor; 2011.

Received on: 01/02/2018

Accepted for publication: 13/03/2018

Conflict of interest: None.

Funding source: CAPES Masters Scholarship.

\section{Mailing address:}

Rosana Maria Resende Lacerda

E-mail: lacerda.rosana@yahoo.com.br / alessandra_castanha@yahoo.com.br

(cc) BY 